\title{
PENENTU STRUKTUR MODAL: BUKTI DARI PERUSAHAAN SYARIAH DI INDONESIA
}

\author{
Habibur Rachman Nur \\ Megister Ekonomi Syariah, Fakultas Ekonomi Dan Bisnis Islam, Universitas \\ Islam Negeri Sunan Kalijaga Yogyakarta \\ habibur14423065@gmail.com \\ \begin{tabular}{l|l|l}
\hline Diterima: Mei 2020 & Direvisi : Oktober 2020 & Diterbitkan: November 2020 \\
\hline
\end{tabular}
}

\begin{abstract}
Capital structure decisions are one of the most important issues in financial management that can contribute to maximizing corporate value. Likewise, decisions about capital structure affect capital costs and capital budgeting decisions. The purpose of this study is to study the chosen research variables on leverage in accordance with the Özde Öztekin empirical investigation, most of the determinants of companies, industries, and macroeconomics are company size, tangibility, industrial leverage, profit, and which relate capital structure theory according to company needs in sharia companies in Indonesia using multiple regression analysis. Samples used from companies registered in the Jakarta Islamic Index (JII) during the period 2016 to 2018 were 18 companies. The results show that industrial leverage variables have a positive and significant relationship with leverage according to the trade off theory, the greater the industrial leverage, the higher and there is a significant inverse relationship between firm size and leverage based on pecking order theory, the greater the size of the company needed fewer and fewer companies are used.
\end{abstract}

Keywords: Capital structure, Sharia Companies, Jakarta Islamic Index, Indonesia. 


\begin{abstract}
Abstrak
Keputusan struktur modal adalah salah satu masalah terpenting dalam manajemen keuangan yang dapat berkontribusi untuk memaksimalkan nilai perusahaan. Demikian juga, keputusan struktur modal mempengaruhi biaya modal dan keputusan penganggaran modal. Tujuan dari penelitian ini adalah untuk menguji pengaruh variabel yang dipilih terhadap leverage sesuai dengan penyelidikan empiris Özde Öztekin, sebagian besar faktor penentu perusahaan, industri, dan makroekonomi adalah ukuran perusahaan, tangibilitas, leverage industri, laba, dan inflasi yang menghubungkan teori struktur modal berdasarkan pembiayaan perusahaan di perusahaan-perusahaan syariah di Indonesia menggunakan analisis regresi berganda. Sampel yang digunakan dari perusahaan yangkonsistenterdaftar di Jakarta Islamic Index (JII) selama periode 2016 hingga2018 yaitu sebanyak 18 perusahaan. Hasil menunjukkan bahwa variabel leverage industri memiliki hubungan yang positif dan signifikan dengan leverage sesuai dengan teori trade off, semakin besar leverage industri semakin tinggi pembiayaan hutang. Dan ada hubungan terbalik yang signifikan antara ukuran perusahaan dan leverage mengacu pada teori pecking order, semakin besarukuran perusahaan yang dimiliki perusahaan semakin sedikit hutang yang digunakan.
\end{abstract}

Kata Kunci: Struktur modal, Perusahaan Syariah, Jakarta Islamic Index, Indonesia.

\title{
A. Latar Belakang
}

Akses ke pembiayaan perusahaan dan biayanya merupakan dimensi penting dari persaingan antara perusahaan dan keputusan mengenai pilihan dari optimalisasi struktur modal sangatlah penting dalam nilai perusahaan yang maksimal, dan juga dalam merangsang pertumbuhan manfaat pemegang saham yang ada, hal tersebut berhubungan kuat dengan metode pembiayaan jangka panjang yang digunakan oleh suatu perusahaan. Pilihan bauran pembiayaan jangka panjang yang digunakan oleh perusahaan disebut struktur modal, terdiri dari pembiayaan dari utang, ekuitas dan sekuritas hibrid yang digunakan perusahaan untuk menghasilkan aset, operasi, dan pertumbuhan di masa depan. Struktur modal perusahaan mencerminkan rasio hutang terhadap modal dalam pilihan pembiayaan. Sehingga, keputusan struktur modal merupakan 
suatu masalah terpenting dalam manajemen keuangan yang dapat berkontribusi untuk memaksimalkan nilai perusahaan. Demikian juga, keputusan struktur modal mempengaruhi biaya modal dan keputusan penganggaran modal. Dalam makalah Modigliani dan Miller menunjukkan bahwa struktur modal atau metode pembiayaan tidak relevan dengan nilai perusahaan di bawah asumsi pasar yang sempurna ${ }^{1}$. Sedangkan Modigliani dan Millerberpendapat bahwa struktur modal relevan dengan nilai perusahaan di bawah kondisi perpajakan².

Menurut Esperança dan Matias, perusahaan memiliki dua bentuk untuk membiayai aset mereka: ekuitas, utang atau, lebih sering kombinasi keduanya. Ekuitas menyatakan uang yang diinvestasikan oleh pemegang saham dan memberikan pembiayaan jangka panjang karena tidak wajib melakukan pembayaran yang efektif. Ada pengembalian terkait yang diharapkan oleh pemegang saham untuk risiko berkelanjutan, yang tergantung pada profitabilitas perusahaan. Namun, jika pengembalian ini dos tidak memenuhi pemegang saham berharap perusahaan tidak harus dalam situasi kebangkrutan. Di sisi lain sebaliknya, utang mengacu pada uang yang diinvestasikan di perusahaan oleh kreditor, yang mewakili kewajiban dan pembayaran yang efektif, umumnya terkait dengan suku bunga dan tanggal jatuh tempo. Apalagi mengeluarkan hutang secara konsekuen akan meningkatkan risiko dan potensi pengembalian ekuitas. Utang dapat dibagi lagi menjadi utang jangka pendek dan jangka panjang sesuai dengan jatuh tempo. Jadi, instrumen jangka pendek lebih relevan ketika perusahaan memiliki kebutuhan modal kerja dan membeli peralatan kecil, sedangkan instrumen jangka panjang lebih penting ketika melakukan investasi baru dan membeli peralatan baru"3. Cara perusahaan membiayai asetnya beberapa kombinasi ekuitas

Modigliani, Franco and Miller, Merton H, "The Cost of Capital, Corporation Finance and the Theory ofInvestment", American Economic Review, 48 (3) June1958, h. 261-297.

${ }^{2}$ Modigliani, Franco and Miller, Merton H,“Corporate Income Taxes and the Cost of Capital: ACorrection”, American Economic Review, 53 (3) June1963, h. 433443. Texto, 2009.

3 J. Esperança and F. Matias, "Finanças Empresariais”, Lisboa, Dom Quixote: 
dan hutang, menyatakan struktur permodalannya. Myers, salah satu yang paling bergengsi peneliti di lapangan, mengasumsikan "tidak ada teori universal tentang pilihan hutang-ekuitas, dan tidak ada alasan untuk harapkan"4.

Teori struktur modal yang menjelaskan perilaku perusahaan dalam memilih pembiayaannya adalah teori trade-off dan teori pecking order. Teori trade-off, timbul sebagai hasildiskusi tentang Modigliani-Miller theorem, klaim bahwa suatu perusahaan akan meminjam sampai pada titik di mana nilai marginal dari pengurangan pajak atau perisai pajak atas bunga yang dibayar untuk kontrak pinjaman akan diimbangi dengan peningkatan nilai sekarang dari biaya kebangkrutan ${ }^{5}$.Pengembangan versi tradisional dari teori trade-off yang dikerjakanKraus dan Litzenbergermenunjukkan bahwa nilai pasar perusahaan dengan leverage serupa dengan nilai pasar dari perusahaan yang tidak bergantung pada leverage sama sekali, kemudian ditambah dengan nilai sekarang pajak pengurangan bunga yang digunakan untuk membayar atas hutang, dikurangi nilai sekarang dari biaya kebangkrutan; berdasarkan itu, tingkat optimal hutang suatu perusahaan mencerminkan keseimbangan antara biaya kebangkrutan dan manfaat pajak dari hutang ${ }^{6}$. Teori trade-off statis mengusulkan bahwa perusahaan menyeimbangkan manfaat dan biaya dari pilihan pembiayaan mereka.Perusahaan lebih menyukai pembiayaan utang daripada menerbitkan ekuitas karena keuntungan dari pelindung pajak utang.Ada juga biaya kebangkrutan, biaya kesulitan keuangan untuk pembiayaan utang.Semakin banyak hutang digunakan, semakin banyak pula kesulitan keuangan; semakin tinggi rasio utang, semakin tinggi pula kemungkinan kebangkrutan. Biaya lain yang dapat ditimbang terhadap manfaat pajak utang adalah biaya agensi. Ini menjelaskan bahwa manajer dari perusahaan yang diungkit cenderung untuk mentransfer risiko jika perusahaan

${ }^{4}$ Stewart C. Myers, "Capital Structure," Journal of Economic Perspectives 15, no. 2 (2018): 87-96. h. $81-102$.

${ }^{5}$ Myers, S., "Capital structure", Journal of Economic Perspectives, vol. 15, 2001,

${ }^{6}$ Kraus, A., and Litzenberger, R.H., "A State-Preference Model of Optimal FinancialLeverage", Journal ofFinance, vol.28, 1973, h. 911-922. 
memiliki arus kas bebas.Terutama, mereka menyukai proyek berisiko yang menguntungkan pemegang saham jika sukses, tetapi membuat kerugian pada pemegang obligasi jika gagal.Dengan demikian, investor obligasi rasional mencegah masalah investasi berlebih dengan menuntut premi risiko dan pembayaran bunga yang lebih tinggi sebagai kompensasi dari perilaku ini. Jenis biaya agensi ini mengurangi daya tarik bagi perusahaan untuk menerbitkan utang. Ini adalah hipotesis pemindahan risiko.

Teori utama berikutnya dari struktur modal adalah teori pecking order. Teori ini disampaikan pertama kali oleh Myers dan Majluf $^{7}$ dan Myers $^{8}$. Teori ini didasarkan pada informasi asimetris antara manajer dengan investor luar yang mengarah ke seleksi yang merugikan sehingga manajer akan mengeluarkan ekuitas baru ketika perusahaan dinilai terlalu tinggi saja. Teori ini tidak memiliki prediksi tentang rasio leverage yang optimal, tetapi pilihan modal perusahaan adalah hasil dari kebutuhan pembiayaan perusahaan dari waktu ke waktu dengan meminimalkan biaya seleksi yang merugikan. Teori pecking order memeringkat sumber-sumber pembiayaan sesuai dengan tingkat mereka dipengaruhi oleh informasi asimetris, di mana dana internal menunjukkan biaya terendah seleksi yang merugikan dan pembiayaan ekuitas memiliki biaya seleksi merugikan tertinggi. Oleh karena itu perusahaan pertama-tama menggunakan dana dari internal untuk mencegah informasi asimetris dan masalah yang merugikan dari seleksi, selanjutnya perusahaan akan menggunakan penerbitan utang karena klaim utang tetap; sekuritas hybrid adalah cara pembiayaan selanjutnya; dan penerbitan ekuitas adalah pilihan pembiayaan terakhir.

Sesuai dengan penyelidikan empiris Özde Öztekin, sebagian besar faktor penentu di tingkat perusahaan, industri, dan makroekonomi yang andal adalah ukuran perusahaan, tangibilitas, leverage industri, laba, dan inflasi.Faktor-faktor penentu ini

${ }^{7}$ Myers, Stewart C. and Majluf, N,“Corporate Financing and Investment Decisions When Firms Have Information That Investor Do Not Have", Journal of Financial Economics, 13 (2)1984, h.187-222.

${ }^{8}$ Stewart C. Myers, “The Capital Structure Puzzle," The Journal of Finance 39, no. 3 (1984): 575. 
memberikan gambaran yang kuat tentang pola dasar dalam data internasional: i) perusahaan yang lebih besar, perusahaan yang mempunyai aset yang lebih nyata, dan perusahaan yang bersaing dalam industri di mana medianperusahaan memiliki leverage yang tinggi lebih condongmempunyaileverage yang tinggi; ii) perusahaan yang mempunyailebih banyak keuntungan lebih condongmempunyaileverage yang lebih sedikit; dan iii) perusahaan yang beroperasi di lingkungan inflasi lebih condongmempunyaitingkat leverage yang rendah?

Penelitian ini bertujuan untuk menguji pengaruh dari variabel yang dipilih yang menghubungkan teori struktur modal berdasarkan pembiayaan perusahaan di perusahaan-perusahaan syariah di Indonesia.Data sekunder berupa data tahunan pada perusahaanyang selaluterdaftar di Jakarta Islamic Index (JII) selama periode 2016 hingga2018 yaitu sebanyak 18 perusahaan. Sumber data leverage, ukuran perusahaan, tangibilitas, leverage industri, dan laba dalam penelitian ini diperoleh melalui situs Bursa Efek Indonesia. Sedangkan sumber data inflasi diperoleh melalui situs Bank Indonesia.

Variabel dependen adalah rasio leverage(LEVERAGE: (Hutang jangka panjang + Hutang jangka pendek) / Total asset). Variabel penjelas adalah faktor penentu perusahaan, industri, dan makroekonomi struktur modalpilihan pembiayaan khusus perusahaan yangdiadopsi dari penelitian sebelumnya Özde Öztekin yaitu:Ukuran perusahaan, (In (TOTAL ASET): Log natural dari total aset), Tangibilitas, (TANGIBILITAS: Aset tetap / Total aset), Leverage industri, (LEVERAGE INDUSTRI: Rasio leverage median tahun sebelumnya untuk industri perusahaan), Laba, (LABA: (Pendapatan operasi + Bunga dan biaya terkait + Pajak penghasilan saat ini) / Total asset), Inflasi. (INFLASI: Pertumbuhan tahunan dalam indeks harga konsumen).

${ }^{9}$ Özde Öztekin, "Capital Structure Decisions around the World: Which Factors Are Reliably Important?",Journal Of Financial And Quantitative Analysis, Vol. 50, No. 3, June2015, h. 301-323. 
Teori trade-off struktur modal memprediksi bahwa leverage meningkat dengan ukuran perusahaan, tangibilitas, leverage industri, laba, dan inflasi. Namun demikian, teori pecking order memprediksibahwa leverage berkurang dengan ukuran perusahaan, tangibilitas, leverage industri, laba, dan inflasi.

Analisis regresi berganda digunakan untuk menguji hubungan antara struktur modal perusahaan danvariabel penjelas terkait. Spesifikasi sebagai berikut:

Rasio leverage $=\mathrm{f}$ (ukuran perusahaan, tangibilitas, leverage industri, laba, dan inflasi)

$$
\text { Yit }=\beta 0+\beta 1 \text { it } \mathrm{X} 1 \text { it }+\beta 2 \text { it } \mathrm{X} 2 \text { it }+\beta 3 \text { it } \mathrm{X} 3 \text { it }+\beta 4 \text { it } \mathrm{X} 4 \text { it }+\beta 5 \text { it } \mathrm{X} 5 \text { it }+\varepsilon
$$

Dimana:

Y adalah rasio leverage buku dan nilai pasar untuk perusahaan i periode t. Sedangkan X adalah salah satu darideterminan (ukuran perusahaan, tangibilitas, leverage industri, laba, dan inflasi) yang mempengaruhi struktur modal perusahaan untuk perusahaan i periode t. $\varepsilon$ adalah sebuahistilah kesalahan.

\section{B. Hasil dan Pembahasan}

Statistik deskriptif dari semua variabel penjelas disajikan pada Tabel 1. Nilai minimum, nilai maksimum, nilai mean dan nilai standar deviasi tiap-tiap ukuran perusahaan adalah 12.09,32.45, 22.2519dan 6.39433. Nilai minimum, nilai maksimum, nilai mean dan nilai standar deviasi dari tiap-tiap tangibilitas adalah 0.02, 0.70, 0.2921 dan 0.21117. Nilai minimum, nilai maksimum, nilaimean dan nilai standar deviasi tiap-tiap leverage industry adalah $0.16,0.77$, 0.4881 dan 0.16499. Nilai minimum, nilai maksimum, nilai mean dan nilai standar deviasi tiap-tiap laba adalah $0.19,2.39,0.7922$ dan 0.55019. Nilai minimum, nilai maksimum, nilai mean dan nilai standar deviasi tiap-tiap inflasi adalah 2.79\%, 4.45\%, 0.0351 dan 0.00444.Selain itu, tiap-tiap leverage memiliki nilai minimum, nilai maksimum, nilai rata-rata dan nilai standar deviasi sebesar 0.14 , $0.77,0.4861$ dan 0.16539 . 
Tabel 1. Statistik Deskriptif

\begin{tabular}{lcccc}
\hline$(\mathrm{N}=53)$ & Minimum & Maximum & Mean & Std deviation \\
\hline Ukuran perusahaan & 12.09 & 32.45 & 22.2519 & 6.39433 \\
\hline Tangibilitas & 0.02 & 0.70 & 0.2921 & 0.21117 \\
\hline Leverage industri & 0.16 & 0.77 & 0.4881 & 0.16499 \\
\hline Laba & 0.19 & 2.39 & 0.7922 & 0.55019 \\
\hline Inflasi & $2.79 \%$ & $4.45 \%$ & 0.0351 & 0.00444 \\
\hline Leverage & 0.14 & 0.77 & 0.4861 & 0.16539 \\
\hline
\end{tabular}

Sumber: Data diolah 2020

Tabel 2 menyajikan hasil dari ujinormalitas. Uji normalitas bertujuan untuk mengujiapakah pada model regresi, variabel pengganggu atauresidual memiliki distribusi yang normal. Uji normalitas menguji t dan F yang mengasumsikanbahwa nilai residual mengikuti distribusi normal. Apabila nilai probability dalam analysis grafik lebih besar dari 0,05 atau 5\% maka dapat dikatakan bahwa data residual terdistribusi secara normal. Hasilnya menunjukan bahwa Tidak ada masalah normalitas secara statistik yang terlihat dari Probability 0.174800> tingkat kesalahan 5\%.

Tabel 2. Hasil Uji Normalitas

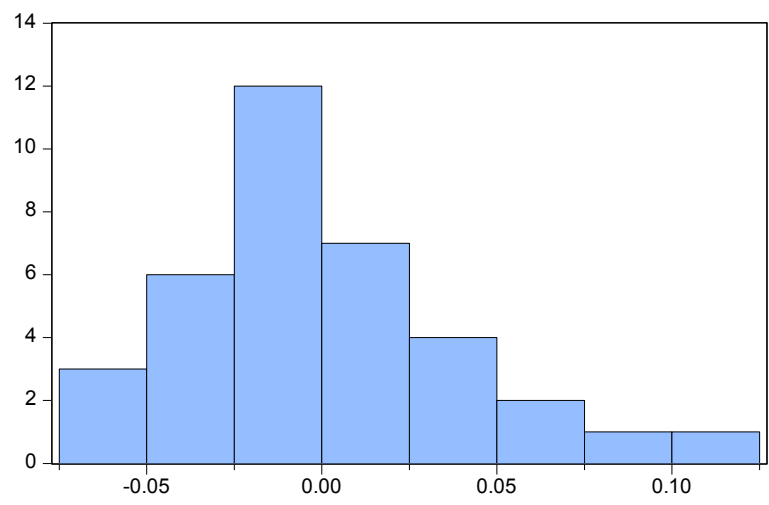

\begin{tabular}{|ll|}
\hline \multicolumn{2}{|l|}{ Series: Residuals } \\
Sample 1 36 \\
Observations & 36 \\
Mean & $-4.00 \mathrm{e}-17$ \\
Median & -0.006527 \\
Maximum & 0.112306 \\
Minimum & -0.074488 \\
Std. Dev. & 0.039997 \\
Skewness & 0.666890 \\
Kurtosis & 3.739267 \\
& \\
Jarque-Bera & 3.488230 \\
Probability & 0.174800 \\
\hline
\end{tabular}

Sumber: Data diolah 2020

Tabel 3 menyajikan hasil dari uji asumsi multikolinieritas. Uji multikolonieritas memiliki tujuan untuk menguji apakah di dalam model regresi ditemukanadanya korelasi antar variabel independen (bebas). Model regresi dianggap baik apabila tidakterdapat korelasi 
antar variabel independen. Hasilnya dari perhitungan Centered variance inflation factor (VIF) bahwa semua variabel memiliki nilai yang kurang dari 10 , jadi tidak ada masalah multicallinearity secara statistic di semua model menurut Centered variance inflation factor (VIF).

\section{Tabel 3. Hasil Uji Multikolinieritas}

Variance Inflation Factors

Date: 07/13/20 Time: 22:34

Sample: 154

Included observations: 36

\begin{tabular}{cccc}
\hline Variable & $\begin{array}{c}\text { Coefficient } \\
\text { Variance }\end{array}$ & $\begin{array}{c}\text { Uncentered } \\
\text { VIF }\end{array}$ & $\begin{array}{c}\text { Centered } \\
\text { VIF }\end{array}$ \\
\hline C & 0.007553 & 145.6954 & NA \\
SIZE & $1.54 \mathrm{E}-06$ & 16.39918 & 1.147983 \\
TANGIBILITAS & 0.002976 & 7.289807 & 1.890942 \\
LEVERAGEINDUSTRY & 0.004466 & 18.62435 & 1.988517 \\
LABA & 0.000259 & 4.221556 & 1.133369 \\
INFLASI & 3.694680 & 89.29349 & 1.368355 \\
\hline
\end{tabular}

Sumber: Data diolah 2020

Tabel 4 menyajikan hasil dari uji asumsi autokorelasi. Tidak ada masalah autokorelasi secara statistik yang terlihat dari Prob. Chi-Square(2) yaitu 0.2671> tingkat kesalahan 5\%

Tabel 4. Hasil Uji Autokorelasi

Breusch-Godfrey Serial Correlation LM Test:

\begin{tabular}{llll}
\hline F-statistic & 1.108149 & Prob. F(2,28) & 0.3442 \\
\hline Obs*R-squared & 2.640519 & Prob. Chi-Square(2) & 0.2671 \\
\hline
\end{tabular}

Sumber: Data diolah 2020

Tabel 5 menyajikan hasil dari uji asumsi heteroskedastisitas. Tidak adaheteroskedastisitas secara statistik yang terlihat dari probabilitas $\mathrm{F}$ hitung > tingkat kesalahan $5 \%$. 
Tabel 5 Hasil Uji Heteroskedastisitas

Heteroskedasticity Test: White

\begin{tabular}{llll}
\hline \hline F-statistic & 2.770413 & Prob. F(20,15) & 0.0244 \\
Obs*R-squared & 28.33044 & Prob. Chi-Square(20) & 0.1018 \\
Scaled explained SS & 26.94606 & Prob. Chi-Square(20) & 0.1368 \\
\hline
\end{tabular}

Sumber: Data diolah 2020

Tabel 6 menyajikan hasil dari uji model regresi linier berganda.

Hasil menunjukkan bahwa nilai prob t-statisitic dari leverage industry (0.0000) lebih kecil dari tingkat kesalahan 5\%. Artinya bahwa variabel leverage industry memiliki hubungan positif dan signifikan terhadap leverage sesuai dengan teori dari trade off, yang menyatakan bahwa semakin besar leverage industry maka semakin tinggi pembiayaan hutang.

Hasil lainnya menunjukkan bahwa nilai prob t-statisitic dari size (0.7555), tangibilitas (0.5661), laba (0.7186) dan inflasi (0.7118) lebih besar dari tingkat kesalahan 5\%. Artinya bahwa variabel tersebut memiliki hubungan negatif terhadap leverage. Variabel size memiliki tingkat prob paling besar dari varibel lainnya, yang artinya bahwa ada hubungan terbalik yang signifikan antara ukuran perusahaan (size) dan leverage mengacu pada teori pecking order. Semakin besar ukuran perusahaan yang dimiliki perusahaan semakin sedikit hutang yang digunakan.

Nilai uji $\mathrm{F}$ atau uji kecocokan model didapat pada baris $\mathrm{f}$ statistic 81.38597dengan prob(f statistik) sebesar 0.000000 lebih kecil dari tingkat kesalahan 5\% artinya variabel independent secara bersama sama bepengaruh terhadap variable dependen.

Nilai koefisien determinasi dinyatakan pada baris R-square sebesar 0.931339yang artinya variabel independent berpengaruh terhadap variabel dependen sebesar 93\% sedangkan sisanya7\% dipengaruhi faktor lain.

Nilai koefisien determinasi yang telah terkoreksi oleh nilai standar error dinyatakan pada baris adjusted R-square sebesar 
0.919896 yang artinya variabel independent berpengaruh terhadap variabel dependen sebesar 91\% sedangkan sisanya 9\% dipengaruhi faktor lain. Sedangkan nlai standar error model regresi $0.043202 \mathrm{di}$ tunjukkan pada baris S.E. of regression. Nilai ini lebih kecil dari pada nilai standar deviasi variabel response yang ditunjukkan pada baris S.D. dependent var yaitu sebesar 0.152641 yang dapat diartikan bahwa model regresi valid sebagai model predictor.

\section{Tabel 6 Hasil uji model regresi linier berganda}

Dependent Variable: LEVERAGE

Method: Least Squares

Date: $07 / 13 / 20$ Time: 22:17

Sample (adjusted): 136

Included observations: 36 after adjustments

\begin{tabular}{lrlrr}
\hline \multicolumn{1}{c}{ Variable } & Coefficient & Std. Error & t-Statistic & Prob. \\
\hline C & -0.043990 & 0.086910 & -0.506150 & 0.6165 \\
$\quad$ SIZE & 0.000389 & 0.001239 & 0.314309 & 0.7555 \\
TANGIBILITAS & 0.031652 & 0.054555 & 0.580193 & 0.5661 \\
LEVERAGEINDUSTRY & 0.995280 & 0.066829 & 14.89288 & 0.0000 \\
$\quad$ LABA & -0.005855 & 0.016096 & -0.363728 & 0.7186 \\
\multicolumn{1}{c}{ INFLASI } & 0.716780 & 1.922155 & 0.372905 & 0.7118 \\
\hline R-squared & 0.931339 & Mean dependent var & 0.432500 \\
Adjusted R-squared & 0.919896 & S.D. dependent var & 0.152641 \\
S.E. of regression & 0.043202 & Akaike info criterion & -3.294868 \\
Sum squared resid & 0.055991 & Schwarz criterion & -3.030948 \\
Log likelihood & 65.30763 & Hannan-Quinn criter. & -3.202753 \\
F-statistic & 81.38597 & Durbin-Watson stat & 2.452241 \\
Prob(F-statistic) & 0.000000 & & \\
\hline
\end{tabular}

Sumber: Data diolah 2020

\section{Kesimpulan}

Struktur modal penting bagi perusahaan untuk menghasilkan aset, operasi, dan pertumbuhan di masa depan, dan akhirnya hasil untuk memaksimalkan penilaian perusahaan. Dengan demikian, apa yang menentukan struktur modal perusahaan adalah pertanyaan dasar dari penelitian ini. Sesuai dengan penyelidikan empiris Özde Öztekinsebagian besar faktor penentu perusahaan, industri, dan 
makroekonomiuntuk perusahaan yang terdaftar di Jakarta Islamic indeks, studi ini mengkonfirmasi bahwa rasio leverage meningkat dengan leverage industri, dan menurun dengan ukuran perusahaan yang signifikan. Meskipun demikian, tidak ada hubungan yang signifikan antara laba, tangibilitas, dan inflasiterhadap rasio leverage. Singkatnya, leverage industry dan ukuran perusahaan merupakan penentu yang signifikan dari struktur modal di perusahaan yang terdafar di JII.

\section{DAFTAR PUSTAKA}

Esperança, J., and F. Matias. Finanças Empresariais. Lisboa, Dom Quixote: Texto, 2009.

Kraus, A., and Litzenberger, R.H., "A State-Preference Model of Optimal Financial Leverage", Journal of Finance, vol.28, 1973.

Modigliani, Franco, and Merton H. Miller. “Corporate Income Taxes and the Cost of Capital: A Correction Author ( $\mathrm{s}$ ): Franco Modigliani and Merton H. Miller Source: The American Economic Review, Vol . 53 , No . 3 ( Jun ., 1963 ), Pp . 433-443 Published by: American Economic Association Stable." The American Economic Review 53, no. 3 (1963): 433-43.

Modigliani, Franco and Miller, Merton H,“The Cost of Capital, Corporation Finance and the Theory of Investment", American EconomicReview. 48 (3) June1958.

Myers, Stewart C. "Capital Structure." Journal of Economic Perspectives 15, no. 2 (2018): 87-96.

_-_. "The Capital Structure Puzzle." The Journal of Finance 39, no. 3 (1984): 575.

Myers, Stewart C., and N Majluf. "Corporate Financing and Investment Decisions When Firms Have Information That Investors Do Not Have." Journal of Financial Economics 13, no. 2 (1984): 187-221.

Öztekin, Özde. “Capital Structure Decisions around the World: Which Factors Are Reliably Important?" Journal of Financial and Quantitative Analysis 50, no. 3 (2015): 301-23. 